\title{
Metode Story Telling dalam Meningkatkan Motivasi Belajar Sejarah Kebudayaan Islam
}

\author{
Hambali, Fathor Rozi, Hayati \\ Universitas Nurul Jadid, Probolinggo, Jawa Timur \\ hambali.amien@gmail.com, fathorrozi330@gmail.com, \\ fidaaprilia08@gmail.com
}

\begin{abstract}
This study aims to analyze and examine the application of the Story Telling method as an effort to increase motivation to learn Islamic Cultural History. The research method used is a descriptive qualitative approach with the type of case study. The research location is in class 5 MI Nurul Mun'im, Paiton District, Probolinggo Regency. Meanwhile, the data collection instruments used in this study included direct observation and unstructured interview notes to support the completeness of the data. Data analysis techniques consist of collecting data, reducing data, presenting data, and then concluding these conclusions. The results obtained from the application of the storytelling method are student learning motivation in following the lesson, students are invited to understand the material in a fun way, namely by telling stories in front of the class. The implication is that students' learning motivation can be achieved by using variations in learning by the teacher so that students do not get bored in class.
\end{abstract}

Keywords: Story Telling, Learning Motivation

\begin{abstract}
Abstrak: Penelitian ini bertujuan untuk menganalisis dan mengkaji penerapan metode Story Telling sebagai upaya meningkatkan motivasi belajar Sejaarah Kebudayaan Islam. Adapun metode penelitian yang digunakan ialah pendekatan kualitatif deskriptif dengan jenis studi kasus. Lokasi penelitian bertempat di kelas 5 MI Nurul Mun'im, Kecamatan Paiton, Kabupaten Probolinggo. Sementara instrumen pengumpulan data yang digunakan dalam penelitian ini antara lain observasi langsung, dan catatan wawancara tidak terstruktur untuk mendukung kelengkapan data. Teknik analisis data terdiri atas tahapan mengumpulkan data, mereduksi data, menyajikan data, dan kemudian menyimpulkan analisis tersebut. Hasil yang diperoleh dari penerapan metode story telling yakni meningkatnya motivasi belajar siswa dalam mengikuti pelajaran SKI sebab siswa diajak untuk memahami inti materi dengan cara yang menyenangkan, yakni dengan bercerita di depan kelas. Implikasinya, motivasi belajar siswa dapat dicapai dengan adanya variasi pembelajaran yang dilakukan guru agar siswa tidak bosan di kelas.
\end{abstract}

Kata kunci: Story Telling, Motivasi Belajar

AR-RIAYAH : Jurnal Pendidikan Dasar vol. 5, no. 2, 2021

IAIN Curup - Bengkulu l p ISSN 2580-362X; e ISSN 2580-3611

http://journal.iaincurup.ac.id/index.php/JPD

DOI: 10.29240/jpd.v5i2.3424 


\section{PENDAHULUAN}

Dalam dunia pendidikan, belajar menjadi aktivitas vital dan pokok yang dilakukan oleh siswa dengan bimbingan seorang guru. Kegiatan belajar bertujuan untuk mengubah sikap dan tingkah laku siswa ke arah yang lebih baik. Untuk dapat mencapai tujuan tersebut, diperlukan sebuah motivasi untuk mendorong siswa ${ }^{1}$. Motivasi belajar dibutuhkan oleh siswa sebab menjadi penentu intensitas usaha belajar yang dapat meningkatkan hasil belajar siswa ${ }^{2}$. Dari sini dapat dilihat pentingnya sebuah motivasi bagi siswa dalam sebuah pembelajaran.

Terkait dengan motivasi belajar, ternyata hal tersebut dapat dipicu dengan proses komunikasi yang aktif antara siswa dan guru. Hal itu sebenarnya telah ditegaskan dalam UU Nomor 20 Tahun 2003 pasal 1 butir 20 tentang Sisdiknas yang menyatakan bahwa interaksi peserta didik dengan pendidik merupakan proses komunikasi dua arah melalui kegiatan belajar dan mengajar ${ }^{3}$. Komunikasi dua arah dalam sebuah pembelajaran yang aktif dapat ditunjukkan dengan melibatkan siswa untuk melakukan suatu aktivitas di kelas ${ }^{4}$. Keterlibatan seperti itu dapat menumbuhkan rasa senang dan semangat belajar yang kemudian akan membangkitkan motivasi dalam diri siswa.

Secara psikologis, sebuah motivasi menjadi faktor penentu keberhasilan dari setiap aktivitas yang dilakukan manusia ${ }^{5}$, tak terkecuali dalam kegiatan belajar. Dalam konteks ini, motivasi menjadi hal penting untuk diperhatikan oleh guru, terlebih ketika mengampu sebuah pelajaran yang mengharuskan banyak hafalan seperti Sejarah

${ }^{1}$ Amna Emda, "Kedudukan Motivasi Belajar Siswa Dalam Pembelajaran," Lantanida Journal 5, no. 2 (2018): 172, https://doi.org/10.22373/lj.v5i2.2838.

2 Nurul Hidayah and Witri Anisa, "Peningkatan Motivasi Belajar Dan Kemampuan Berpikir Kritis Peserta Didik Menggunakan Model Think Pair Share Berbantuan Alat Peraga Bahan Bekas," AR-RIAYAH: Jurnal Pendidikan Dasar 3, no. 2 (2019): 165, https://doi.org/10.29240/jpd.v3i2.1186.

${ }^{3}$ S. Syaparuddin, M. Meldianus, and E. Elihami, "Strategi Pembelajaran Aktif Dalam Meningkatkan Motivasi Belajar PKn Peserta Didik," MAHAGURU: Jurnal Pendidikan Guru Sekolah Dasar 2, no. 1 (2020): 31-42, https://ummaspul.ejournal.id/MGR/article/download/326/154.

${ }^{4}$ Wakhidati Nurrohmah Putri, "Pengaruh Media Pembelajaran Terhadap Motivasi Belajar Bahasa Arab Siswa Madrasah Tsanawiyah," LISANLA: Journal of Arabic Education and Literature 1, no. 1 (2017): 1-16, https://doi.org/10.18326/lisania.v1i1.817.

${ }^{5}$ Muhammad Kamaluddin, "Pengaruh Motivasi Belajar Terhadap Prestasi Belajar Matematika Dan Strategi Untuk Meningkatkannya," Seminar Matematika Dan Pendidikan Matematika 67, no. 9 (2017): 455-60. 
Kebudayaan Islam. Ketika guru hanya menerapkan metode mengajar konvensional seperti ceramah, yang terjadi hanyalah siswa menjadi pasif, malas, dan tidak bergairah di kelas sebab hanya mendengarkan penjelasan guru ${ }^{6}$. Sebagaimana yang pernah terjadi di SMP Negeri 2 Gamping dalam penelitian Lestari dkk., saat motivasi belajar siswa kurang, yang terjadi adalah siswa tidak aktif dalam pembelajaran ${ }^{7}$. Adapula penelitian yang menyebutkan bahwa ketika siswa tidak memiliki motivasi belajar, maka siswa tidak tertarik untuk menyimak penjelasan guru di dalam kelas ${ }^{8}$. Keadaan seperti itu dapat mengurangi keefektifan belajar, sehingga hasil belajar yang hendak dicapai tidak maksimal.

Sebagai salah satu mata pelajaran di tingkat Madrasah Ibtidaiyah, Sejarah Kebudayaan Islam menekankan pemahaman esensi, makna, nilai, serta kronologi histori dari perjalanan dakwah Islam pada setiap mas? . Dalam pembelajaran, menanamkan pemahaman dari peristiwa sejarah seperti demikian kerap dilakukan dengan metode ceramah yang kurang menarik bagi siswa. Tidak hanya itu, penamanan pemahaman materi Sejarah Kebudayaan Islam dengan metode konvensional, tidak dapat mempertahankan atau bahkan meningkatkan konsentrasi siwa pada materi ${ }^{10}$. Akibatnya, nilai-nilai filosofis yang terdapat dalam materi Sejarah Kebudayaan Islam tidak dapat dicerna dengan baik. Keadaan demikian menjadi problematika dalam pelajaran Sejarah Kebudayaan Islam itu sendiri.

Guna mengatasi problematika tersebut, MI Nurul Mun'im membuat sebuah strategi yang kreatif dengan cara menerapkan metode

${ }^{6}$ Fathor Rozi, "Variations in Learning Methods; Upaya Dalam Mencetak Pakar Fiqh Melalui Pengembangan Pembelajaran Kitab Kuning Di Ma'had Aly," Tafaqqub: Jurnal Penelitian Dan Kajian Keislaman 9, no. 1 (2021): 81-98.

${ }^{7}$ Wahyu Lestari, Loviga Denny Pratama, and Jailani Jailani, "Implementasi Pendekatan Saintifik Setting Kooperatif Tipe STAD Terhadap Motivasi Belajar Dan Prestasi Belajar Matematika," AKSIOMA : Jurnal Matematika Dan Pendidikan Matematika 9, no. 1 (2018): 29, https://doi.org/10.26877/aks.v9i1.2332.

${ }^{8}$ Yusri Yusri et al., "Efektivitas Penggunaan Media Youtube Berbasis Various Approaches Dalam Meningkatkan Motivasi Belajar Bahasa Inggris," Eralingua: Jurnal Pendidikan Bahasa Asing Dan Sastra 2, no. 2 (2018): 77-82, https://doi.org/10.26858/eralingua.v2i2.6760.

9 Achmad Naim, "Aplikasi Cooperatif Learningtipe Group Investigation ( Gi)Pada Mata Pelajaran Sejarah Kebudayaan Islam Di Kelas V Favoritmi Salafiyah Syafi'iyahsukorejo Situbondo, Tahun Pelajaran 2015/2016," Journal Al Murabbi 3, No. 1 (2016): 92-105.

10 A Andriyansyah, "Penanaman Toleransi Agama Pada Diri Anak Melalui Doktrin Sejarah Kebudayaan Islam (Penelitian Tindakan Kelas Pada Mi Hidayatul Ahbabina, Setu ...," El Banar: Jurnal Pendidikan Dan ... 02 (2019): 121-26. 
story telling. Metode story telling atau bercerita dapat secara efektif membangun imajinasi serta membentuk karakter siswa dari nilai-nilai kisah yang diceritakan tanpa paksaan ${ }^{11}$. Selain itu, metode story telling menjadi cara penyampaian yang bersifat menyenangkan dan tidak menggurui yang dapat merangsang rasa ingin tahu siswa ${ }^{12}$. Ketika rasa ingin tahu siswa muncul tanpa disertai paksaan, hal itu menjadi motivasi baru bagi siswa untuk mempelajari sebuah materi. Dalam penelitian yang dilakukan oleh Azizeh, disebutkan bahwa metode kisah atau story telling dapat membuat peserta didik merasa asyik saat belajar yang merupakan inner motivation, yakni dorongan rasa ingin tahu yang diikuti upaya untuk mencari tahu sesuatu ${ }^{13}$.

Kelebihan lain yang terdapat pada metode story telling dalam pelajaran Sejarah Kebudayaan Islam yakni dapat mempermudah siswa dalam memahami dan memanggil kembali ingatan (recall) suatu pengetahuan daripada ketika pengetahuan tersebut disampaikan secara konvensional (ceramah) yang bersifat informatif ${ }^{14}$. Metode story telling juga dapat mengasah daya tangkap, daya pikir, dan daya konsentrasi siswa namun tetap dalam suasana yang menyenangkan ${ }^{15}$. Maknanya, metode ini dapat menjadi solusi yang menarik dan berkesan dalam meningkatkan motivasi belajar siswa dalam pelajaran Sejarah Kebudayaan Islam yang mengharuskan banyak hafalan.

Dalam penelitian ini, peneliti berupaya untuk mengkaji beberapa penelitian terdahulu yang memiliki relevan dengan fokus penelitian. Pada

\footnotetext{
${ }^{11}$ Sigit Widiyarto et al., "Penguatan Pendidikan Karakter Dan Budi Pekerti Melalui Metode Story Telling Bagi Guru Pondok Darunnadwah Cikarang - Bekasi," Jurnal Pengabdian UntukMu NegeRI 4, no. 2 (2020): 222-27, https://doi.org/10.37859/jpumri.v4i2.2137.

${ }^{12}$ Sandy Ramdhani et al., "Penanaman Nilai-Nilai Karakter Melalui Kegiatan Storytelling Dengan Menggunakan Cerita Rakyat Sasak Pada Anak Usia Dini," Jurnal Obsesi: Jurnal Pendidikan Anak Usia Dini 3, no. 1 (2019): 153, https://doi.org/10.31004/obsesi.v3i1.108.

${ }^{13}$ Siti Nur Azizeh, "Metode Kisah Dalam Meningkatkan Motivasi Belajar Dan Kemampuan Bercerita Pada Pembelajaran Sejarah Kebudayaan Islam Di Madrasah Ibtidaiyah," Al Insyiroh: Jurnal Studi Keislaman 7, No. 1 (2021): 88-114.

14 Indah Perdana Sari, Intan Kurniasari Suwandi, and Susi Setyowati, "Pengaruh Metode Storytelling Terhadap Karakter Kerjasama Pada Siswa Kelas Iii Sd Pujokusuman Yogyakarta," Taman Cendekia: Jurnal Pendidikan Ke-SD-An 2, no. 2 (2018): 231, https://doi.org/10.30738/tc.v2i2.3078.

15 Monry FNG Ratumbuysang, "Penguatan Karakter Wirausaha Melalui Metode Story Telling Sejarah Berdagang Nabi Muhammad Dan Sahabatnya," Jurnal Ecopsy 4, no. 3 (2017): 133, https://doi.org/10.20527/ecopsy.v4i3.4292.
} 
hasil penelitian pertama yang penulis kaji ${ }^{16}$, didapat hasil yang menunjukkan bahwa motivasi belajar Sejarah Kebudayaan Islam pada diri siswa dapat ditingkatkan dengan menggunakan metode kisan sehingga penyampaian materi tidak monoton dan membosan serta mampu menguatkan daya ingat siswa terhadap kisah sejarah yang dituturkan. Sementara pada hasil penelitian kedua ${ }^{17}$ yang peneliti kaji menyatakan bahwa metode story telling yang diterapkan pada materi pelajaran Sejarah Kebudayaan Islam dapat menarik minat siswa, mempermudah daya serap dan daya ingat terhadap materi, serta meningkatkan hasil belajar siswa. Adapun hasil penelitian ketiga ${ }^{18}$ yang dikaji penulis menyatakan bahwa metode kisah dapat menarik perhatian siswa ketika pembelajaran Sejaran Kebudayaan Islam berlangsung dan mengasah daya ingat siswa terhadap cerita yang disampaikan.

Titik perbedaan antara kajian penelitian terdahulu dengan topik dalam penelitian ini terletak pada cara pelaksanaan metode story telling dalam meningkatkan motivasi belajar Sejarah Kebudayaan Islam pada siswa Madrasah Ibtidaiyah Nurul Mun'im (MINM). Pada penerapannya di kelas, guru MINM menerapkan metode story telling secara berkelompok pada setiap akhir bab. Jadi, metode ini juga dapat mengasah keterampilan siswa dalam membangun kerja sama dengan teman untuk dapat menampilkan kisah yang menarik tanpa mengesampingkan nilai-nilai penting yang terdapat dalam materi tersebut.

Sementara itu, Madrasah Ibtidaiyah Nurul Mun'im merupakan lembaga pendidikan tingkat Sekolah Dasar yang berada di bawah naungan Yayasan Pondok Pesantren Nurul Jadid, Paiton, Probolinggo. Meski madrasah ini memiliki basis pesantren, namun metode belajar yang diterapkan tidak seluruhnya bersifat konvensional. Akan tetapi, lembaga ini juga menerapkan berbagai metode baru yang lebih kreatif, menarik, dan mampu mengasah bakat peserta didiknya. Dalam konteks

16 Siti Nur Azizeh, "Metode Kisah Dalam Meningkatkan Motivasi Belajar Dan Kemampuan Bercerita Pada Pembelajaran Sejarah Kebudayaan Islam Di Madrasah Ibtidaiyah," Al Insyirob: Jurnal Studi Keislaman 7, No. 1 (2021): 88-114.

17 Maya Selvia Lauryn, M. Ibrohim, and Mochammad Rizqi Amirullah, "Pengembangan Metode Storytelling Berbasis Game Edukasi Dalam Pembelajaran Sejarah Sahabat Nabi," ProTekInfo(Pengembangan Riset Dan Observasi Teknik Informatika) 6, no. 1 (2019): 21, https://doi.org/10.30656/protekinfo.v6i1.1745.

18 Aslan, "Implementasi Metode Cerita Pada Mata Pelajaran Sejarah Kebudayaan Islam Di Kabupaten Sambas(Studi Kasus Pada Madrasah Ibtidaiyah Swastadarul Ulum Matang Danau Kecamatan Paloh)," Cross Border: Jurnal Kajian Perbatasan Antarnegara, Diplomasi, Dan Hubungan Internasional 2, No. 1 (2019): 50-66. 
ini, metode story telling yang dilakukan pada setiap akhir bab secara berkelompok tentu tidak mudah dilakukan. Guru bukan hanya harus menjelaskan materi pada pertemuan-pertemuan awal, tetapi juga harus mengelompokkan siswa dan mendorong mereka untuk berani tampil di depan kelas. Mengelompokkan siswa bukanlah perkara mudah, sebab, guru hendaknya membentuk kelompok yang homogen berdasarkan kemampuan siswa agar tidak ada siswa yang mendominasi kinerja kelompok sehingga semua anggota kelompok dapat berperan aktif ${ }^{19}$. Hal itulah yang menjadi keunikan tersendiri bagi penelitian ini.

Adapun fokus penelitian dalam penerapan metode story telling dalam meningkatkan motivasi belajar Sejarah Kebudayaan Islam penting untuk dilakukan, sebab kurangnya motivasi belajar, terlebih dalam pelajaran sejarah yang cenderung mengharuskan banyak menghafal kronologi sebuah peristiwa, dapat mempengaruhi hasil belajar siswa. Dengan adanya metode story telling yang menarik dan membuat siswa mengingat kronologi peristwa sejarah tanpa paksaan akan memberi motivasi baru sehingga hasil belajar diharapkan dapat meningkat.

\section{METODE PENELITIAN}

Dalam mengkaji topik ini, peneliti menggunakan pendekatan deksriptif kualitatif guna mendapatkan berbagai informasi dan data yang dibutuhkan dalam meningkatkan motivasi belajar siswa, khususnya dalam pelajaran Sejarah Kebudayaan Islam. Secara lebih spesifik, penelitian ini menggunakan jenis studi kasus untuk memahami sebuah kasus secara mendalam dengan cara mengumpulkan berbagai sumber informasi ${ }^{20}$. Pendekatan dan jenis penelitian ini dipilih untuk menguraikan sebuah kondisi dalam suatu konteks dengan terperinci dan mendalam ${ }^{21}$.

${ }^{19}$ Muhammad Ferry Irwansyah and Endah Retnowati, "Efektivitas Worked Example Dengan Strategi Pengelompokan Siswa Ditinjau Dari Kemampuan Pemecahan Masalah Dan Cognitive Load," Jurnal Riset Pendidikan Matematika 6, no. 1 (2019): 62-74, https://doi.org/10.21831/jrpm.v6i1.21452.

20 Jozef Raco, "Metode Penelitian Kualitatif: Jenis, Karakteristik Dan Keunggulannya," in Grasindo (Grasindo, 2018), https://doi.org/10.31219/osf.io/mfzuj.

21 Nugrahani Farida, Metode Penelitian Kualitatif Dalam Penelitian Pendidikan

Bahasa, Grasindo, vol. $\quad 1, \quad 2014, \quad$ http://e-
journal.usd.ac.id/index.php/LLT\%0Ahttp://jurnal.untan.ac.id/index.php/jpdpb/art icle/viewFile/11345/10753\%0Ahttp://dx.doi.org/10.1016/j.sbspro.2015.04.758\%0

Awww.iosrjournals.org. 
Sebagai sebuah penelitian studi kasus, lokasi penelitian berada di Madrasah Ibtidaiyah Nurul Mun'im, Kecamatan Paiton, Probolinggo. Tepatnya, penelitian dilakukan di kelas 5 MI Nurul Mun'im. Dalam penelitian ini, informan yang menjadi subjek penelitian adalah Ustadzah Qoimah, S.Pd selaku wali kelas 5 dan Ustadzah Zuyyimatur Roizah, S.Pd selaku guru Sejarah Kebudayaan Islam yang menjadi informan primer. Sementara Safira Nayla Farohiyah, Naila Darojatula, dan Salsabila Balqis selaku murid kelas 5 menjadi informan sekunder.

Sementara itu, metode pengumpulan data dilakukan dengan wawancara tidak terstruktur serta observasi. Wawancara tidak terstruktur merupakan wawancara bebas tanpa adanya pedoman wawancara yang telah disusun secara lengkap dan sistematis ${ }^{22}$. Adapun observasi dilakukan dengan cara mengamati objek penelitian, mengajukan pertanyaan, mengumpulkan data, kemudian membuat kesimpulan dari data yang telah disusun ${ }^{23}$. Dari hasil wawancara dan observasi yang dilakukan, peneliti melakukan teknik analisis data yang terdiri atas tahapan mengumpulkan data, mereduksi data, menyajikan data, dan kemudian menyimpulkan analisis tersebut ${ }^{24}$. Pada tahap reduksi data inilah, peneliti berupaya memilih, menyederhanakan, serta meringkas catatan-catatan kasar selama melakukan wawancara dan observasi langsung.

\section{HASIL DAN PEMBAHASAN}

Fokus penelitian ini adalah pada upaya peningkatan motivasi belajar siswa dalam pelajaran Sejarah Kebudayaan Islam di MI Nurul Mun'im. Sebab, dari hasil observasi yang dilakukan di lapangan, siswa kelas 5 MI Nurul Mun'im seringkali tidak tertarik ketika pembelajaran Sejarah Kebudyaan Islam berlangsung.

Untuk meningkatkan motivasi belajar siswa dalam pelajaran Sejarah Kebudayaan Islam di MI Nurul Mun'im, upaya yang dilakukan oleh wali kelas adalah dengan menerapkan metode story telling. Wali kelas

22 Edi surya Shopiah Atikah Dwi, "Penerapan Langkah Polya Dalam Menyelesaikan Soal Cerita Pada Materi Aritmatika Sosial Di SMP," Jurnal Pendidikan Matematika, no. May (2017).

${ }^{23}$ Mashud Syahroni, "PERSEPSI MAHASISWA TERHADAP MANFAAT METODE PEMBELAJARAN OBSERVASI LAPANGAN PADA MATA KULIAH PROFESI KEPENDIDIKAN," Indonesian Journal of Education and Learning 4, no. 1 (2020): 417-24, https://doi.org/10.31002/ijel.v4i1.3253.

${ }^{24}$ Matthew B. Miles, A. Michael Huberman, and Johnny Saldana, "Qualitative Data Analysis: A Methods Sourcebook, 3/E," in Sage Publication, third (New York: SAGE Publications, 2013), 341. 
5 MI Nurul Mun'im mengatakan bahwa metode story telling ini dapat memicu motivasi siswa dalam mengikuti pembelajaran Sejarah Kebudayaan Islam. Hal tersebut dapat dilihat dari nilai capaian siswa di akhir pembelajaran yang dibuat guru.

\section{Metode Story Telling}

Penerapan metode story telling di MI Nurul Mun'im khususnya kelas 5 ini dilakukan mengingat mata pelajaran SKI seringkali membuat siswa merasa bosan. Salah satu siswa kelas $5^{25}$ mengatakan bahwa pelajaran SKI itu sulit untuk dimengerti karena terlalu banyak hal yang harus diingat. Bahkan, wali kelas 5 yang mengampu pelajaran SKI itu sendiri juga berpendapat bahwa guru seringkali kewalahan ketika pelajaran berlangsung. Berikut beberapa bentuk kondisi siswa saat pembelajaran SKI berlangsung ${ }^{26}$.

1. Siswa mengantuk di kelas;

2. Siswa berbicara sendiri ketika guru menjelaskan materi;

3. Siswa tidak aktif atau tidak bisa menjawab pertanyaan guru terkait materi yang disampaikan;

4. Siswa tidak kondusif atau sibuk dengan kegiatan masingmasing yang tidak ada kaitannya dengan pelajaran.

Kondisi-kondisi tersebut melatarbelakangi guru untuk menerapkan sebuah metode pembelajaran yang lebih efektif. Dalam konteks ini, metode yang diterapkan adalah story telling berkelompok. Story telling termasuk dalam seni lisan yang dapat mentransmisikan ilmu pengetahuan, pengalaman orang atau sekelompok, gagasan, perasaan, serta nasihat-nasihat lintas waktu dan budaya yang dapat diterima oleh segala usia mulai anak-anak hingga orang dewasa ${ }^{27}$. Metode ini dipilih mengingat story telling dapat mengasah kemampuan pendongeng dalam menyampaikan sebuah kisah dengan intonasi, gestur, mimik wajah, gaya, serta alat peraga yang mampu menarik minat pendengarnya ${ }^{28}$. Tentunya, 2021, 1.

25 Salsabila Balqis, "Wawancara Siswa," in Siswa Kelas V MI Nurul Mun'im,

${ }^{26}$ Qoimah, "Wawancara Guru,” in Wali Kelas V MI Nurul Mun'im, 2021, 1.

${ }^{27}$ Dwi Puji Lestari, "Peningkatan Perilaku Anti Korupsi Melalui Metode Story Telling," Raudhatul Athfal: Jurnal Pendidikan Islam Anak Usia Dini 2, no. 1 (2018): 95105, https://doi.org/10.19109/ra.v2i1.2238.

28 L. Ariani and D. S. Hariyono, "Storytelling Sebagai Metode Dalam Mengembangkan Kemampuan Berbahasa Pada Anak Prasekolah," Prosiding Seminar Nasional \& Call Paper Psikologi Pendidikan, 2019, 36-44, http://fppsi.um.ac.id/wpcontent/uploads/2019/07/5-STORYTELLING-SEBAGAI-METODE-DALAMMENGEMBANGKAN-KEMAMPUAN-BERBAHASA-PADA-ANAKPRASEKOLAH-36-44.pdf. 
jika sebuah materi disampaikan dengan cara demikian, siswa lain yang mendengarkan temannya mendongeng tidak akan merasa bosan bahkan ingin mengetahui akhir cerita tanpa perasaan tertekan.

Di MI Nurul Mun'im, kemenarikan metode story telling ini juga diimbangi dengan pembentukan kelompok-kelompok homogen. Pembentukan kelompok homogen ini diterapkan bukan tanpa tujuan, melainkan untuk mengelompokkan siswa berdasarkan kemampuan yang sepadan sehingga tidak ada siswa yang merasa minder atau sebaliknya, mendominasi dalam kegiatan kelompok ${ }^{29}$. Dengan demikian, kelompok homogen dapat melatih siswa untuk bekerja sama saling mengisi agar tercapai hasil belajar yang maksimal. Selain itu, salah satu siswa ${ }^{30}$ juga berpendapat, bahwa pembentukan kelompok homogen membuat mereka nyaman dalam berdiskusi karena biasanya secara sosial mereka kerap bermain dan berkumpul bersama.

Adapun tahapan penerapan metode story telling tersebut adalah sebagai berikut.

1. Guru menyiapkan pembelajaran. Sebelum pembelajaran dilakukan, guru membuat RPP (Rencana Pelaksanaan Pembelajaran) sebagai rancangan sistem pembelajaran yang akan diterapkan di kelas. RPP ini dibuat agar kegiatan pembelajaran menjadi lebih mudah dan terarah sehingga dapat mencapai tujuan pembelajaran. Setelah itu, guru harus menyiapkan bahan dan media pembelajaran yang akan digunakan. Menurut wali kelas 5 MI Nurul Mun’im, bahan ajar yang digunakan untuk materi SKI berupa buku LKS. Sementara media yang biasanya digunakan adalah berupa gambar-gambar peristiwa sejarah yang berkaitan dengan materi ataupun gambar tokoh terkait peristiwa tersebut.

2. Guru memulai pembelajaran dengan menyampaikan kompetensi yang harus dicapai siswa pada akhir materi serta tugas yang akan membantu siswa untuk mencapai kompetensi tersebut. Pada tahap ini, guru Sejarah Kebudayaan Islam (SKI) memaparkan kompetensi yang harus dicapai pada satu bab yang akan dipelajari selama 3-4 kali pertemuan berikutnya. Kompetensi SKI yang dimaksud mencakup:

a. pengetahuan (fakta dan informasi penting yang terdapat dalam suatu $\mathrm{bab})$;

${ }^{29}$ W Saugi, "Peningkatan Keaktifan Dan Hasil Belajar Matematika Melalui Penerapan Model Cooperative Learning Berbasis Achievement Grouping ( Clag )," Educasia 3, no. 1 (2018): 1-15, www.educasia.or.id.

${ }^{30}$ Naila Darojatun, "Wawancara Siswa," in Siswa Kelas V MI Nurul Mun'im, 2021, 1. 
b. sikap (karakter yang dapat diteladani dari kisah yang dipelajari), serta

c. keterampilan (kemampuan siswa dalam mengamati lingkungan sekitar yang memiliki relevansi dengan materi).

3. Guru menyampakan materi selama 3-4 kali pertemuan. Pada pelajaran Sejarah Kebudayaan Islam, tiap babnya rata-rata terdiri dari 3 subbab. Setiap subbab biasanya dijelaskan dalam satu waktu pertemuan atau $2 \times 40$ menit. Pada saat menyampaikan materi, guru SKI biasanya akan meminta siswa untuk mencatat poin-poin penting yang harus ditampilkan pada saat story telling.

4. Guru membentuk kelompok homogen berdasarkan kemampuan siswa pada pertengahan materi. Ketika guru SKI sudah menyampaikan 2 atau 3 subbab kepada siswa, guru akan mulai membentuk kelompok yang harus menampilkan story telling pada akhir pertemuan (dalam satu bab) nantinya. Pembentukan kelompok ini dilakukan secara homogen berdasarkan kemampuan siswa. Misalnya, guru akan memilih 3 orang siswa yang kemampuannya hampir sama atau sepadan.

5. Guru meminta siswa untuk menampilkan story telling pada akhir pertemuan. Ketika satu bab sudah selesai dijelaskan semua, kelompok story telling yang sudah dibentuk sebelumnya harus siap tampil di depan kelas. Pada saat tampil, siswa diperboleh membawa alat peraga atau kostum yang dibutuhkan agar penampilan mereka semakin menarik. Alat peraga yang digunakan oleh siswa boleh berupa bendabenda. yang ada di sekitar mereka seperti penggaris yang dianalogikan sebagai pedang, tongkat kayu yang dianalogikan sebagai hewan tunggangan, surban, sarung, serta berbagai benda sederhana lainnya.

Apabila dibentuk alur, maka penerapan metode story telling di MI Nurul Mun'im dapat dilihat pada gambar 1 berikut ini

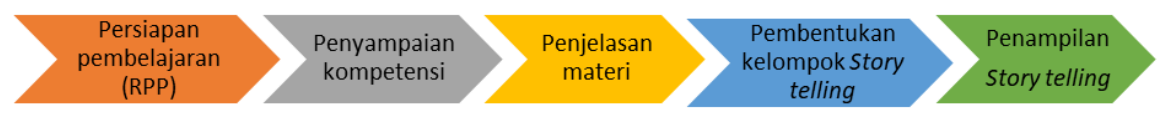

\section{Gambar 1. Alur Penerapan Metode Story Telling Peningkatan Motivasi Belajar Sejarah Kebudayaan Islam}

Dari penerapan metode story telling yang dilaksanakan di kelas 5 MI Nurul Mun'im, wali kelas 5 menyampaikan bahwa sebagian besar siswanya menjadi lebih bersemangat dalam mengikuti pembelajaran SKI. Hal itu terlihat ketika 70\% siswa mengalami kenaikan nilai SKI, dengan keantusiasan dan keaktifan siswa dalam mengikuti pelajaran mencapai $80 \%$. Peningkatan nilai dan keaktifan siswa dapat dicapai sebab siswa 
dituntut untuk menyampaikan ulang inti materi, namun dengan cara yang menarik. Hal tersebut juga disebabkan penyampaian materi dengan metode story telling akan membuat siswa lebih tertarik sehingga memicu mereka untuk memberi tanggapan berupa menyimak kisah yang ditampilkan 31. Ketika siswa tertarik untuk menyimak, hal itulah yang kemudian akan menjadi motivasi mereka untuk lebih semangat mempelajari materi SKI 32. Dengan demikian, hasil belajar yang diperoleh pun dapat meningkat.

Adapun secara signifikan, guru Sejarah Kebudayaan Islam 33 menjelaskan beberapa perubahan yang diperoleh guru atas siswa setelah menerapkan metode story telling dalam pembelajaran SKI antara lain sebagai berikut.

Pertama, siswa semakin rajin mencatat poin-poin penting dari materi yang disampaikan guru sebab mereka dituntut untuk menyampaikan kembali materi tersebut dengan cara story telling. Hal ini dapat membuat kelas menjadi lebih kondusif. Kelas yang kondusif dapat memberi motivasi dan ketahanan belajar bagi siswa, sehingga kualitas belajar mereka pun dapat meningkat 34.

Kedua, siswa mampu memahami inti materi dan meneladani nilainilai yang terkandung dalam peristiwa sejarah dengan baik. Metode story telling atau mendongeng dapat menarik emosi pendengarnya sehingga membekas di hati pendengarnya 35. Hal ini kemudian secara tidak langsung akan mempengaruhi pola pikir dan tindakan mereka dalam kehidupan sehari-hari.

Ketiga, siswa menjadi lebih kreatif dan imajinatif dalam menyampaikan sebuah materi dengan metode story telling. Salah satu

31 Andi Irwan Benardi, "Pendidikan Kesiapsiagaan Bencana Tanah Longsor Untuk Siswa Anak Usia Dini Dengan Metode Dongeng Berbasis Media Pop Up Book Di Paud Dewi Sartika Kecamatan Bergas," Jurnal Pendidikan Geografi 23, no. 2 (2018): 85-93, https://doi.org/10.17977/um017v23i22018p085.

32 Moh. Fauziddin dan Adityawarman Hidayat Resi Amelia Syarwah, "Peningkatan Motivasi Belajar Siswa Menggunakan Media Audio Visual Pada Pembelajaran Bahasa Indonesia," Jurnal Pendidikan Tambusai 3, no. 5 (2019): 936-45.

${ }^{33}$ Zuyyimatur Roizah, "Wawancara Guru," in Guru Sejarab Kebudayaan Islam, vol. 3, 2021, 24090.

34 Jumrawarsi and Neviyarni Suhaili, "Peran Seorang Guru Dalam Menciptakan Lingkungan Belajar Yang Kondusif," Ensiklopedia Education Review 2, no. 3 (2020): 50-54.

${ }^{35}$ Bahrul Ulum, "Metode Kisah Pendidikan Anak Usia Dini Dalam Hadits Nabi," Ta'allum: Jurnal Pendidikan Islam 8, no. 2 (2020): 202-21, https://doi.org/10.21274/taalum.2020.8.2.202-221. 
siswa 36 menyampaikan bahwa, ketika guru meminta siswa untuk menyampaikan materi dengan cara story telling, mereka akan berupaya untuk menyusun alur cerita dengan menarik serta mencari berbagai benda yang dapat mendukung penampilan mereka.

Keempat, siswa semakin aktif dalam merespon materi yang disampaikan guru. Hal ini disebabkan mereka ingin mengetahui peristiwa sejarah yang sedang dibahas secara lebih mendalam agar dapat menampilkan cerita secara tepat dan utuh melalui story telling berkelompok. Penampilan story telling secara berkelompok ini juga menjadi pemicu keaktifan siswa dalam mengikuti kegiatan yang berhubungan dengan materi pelajaran 37. Antara anggota satu dengan anggota laiinya dapat saling membantu agar hasil kerja mereka memuaskan.

Dari beberapa perubahan yang diperoleh guru Sejarah Kebudayaan Islam atas siswa tersebut di atas, terlihat bahwa variasi pembelajaran SKI yang dilakukan dengan cara menerapkan metode story telling dapat meningkatkan motivasi belajar siswa kelas 5 MI Nurul Mun'im.

\section{KESIMPULAN}

MI Nurul Mun'im berinisiatif untuk melakukan variasi pembelajaran Sejarah Kebudayaan Islam (SKI) dengan cara menerapkan metode story telling. Metode ini digunakan untuk meningkatkan motivasi belajar siswa mengingat materi pelajaran SKI berisi peristiwa-peristiwa sejarah yang tidak jarang membuat siswa merasa kesulitan untuk mengingatnya. Dengan menerapkan metode story telling, siswa diajak untuk memahami inti materi dengan cara yang menyenangkan, yakni dengan menceritakan peristiwa sejarah tersebut di depan kelas, disertai dengan intonasi, gestur, gaya, serta alat peraga yang menarik. Cara seperti ini dapat menarik perhatian siswa untuk mengikuti setiap adegan dengan antusias. Hasilnya, siswa akan lebih bersemangat dalam mengikuti pelajaran SKI agar mereka dapat menampilkan peristiwa sejarah dengan cara story telling sehingga hasil belajarpun meningkat.

\footnotetext{
Mun'im, 2021, 1.

37 M Irfangi, "Implementasi Metode Kisah Dalam Pembelajaran Akidah Akhlak Di Madrasah Aliyah," Jurnal Kependidikan 5, no. 1 (2017): 87-104, https://doi.org/10.24090/jk.v5i1.1255.
}

${ }^{36}$ Safira Nayla Farohiyah, "Wawancara Siswa," in Siswa Kelas V MI Nurul 
Dari metode story telling ini, diperoleh implikasi bahwa untuk dapat meningkatkan motivasi belajar siswa diperlukan variasi pembelajaran agar siswa tidak merasa bosan di kelas. Hal tersebut mengindikasikan bahwa guru hendaknya kreatif dalam membuat metode pembelajaran. Walau demikian, penggunaan sebuah metode pembelajaran tetap harus disesuaikan dengan kondisi lingkungan belajar serta psikologis siswa agar hasil yang didapat benar-benar efektif.

\section{DAFTAR PUSTAKA}

Andriyansyah, A. "Penanaman Toleransi Agama Pada Diri Anak Melalui Doktrin Sejarah Kebudayaan Islam (PENELITIAN TINDAKAN KELAS PADA MI HIDAYATUL AHBABINA, SETU, BEKASI)." El Banar: Jurnal Pendidikan Dan Pengajaran 02, no. 02 (2019): 121-26. http://ojs.staibanisaleh.ac.id/index.php/ElBanar/article/view/39

Aslan. "IMPLEMENTASI METODE CERITA PADA MATA PELAJARAN SEJARAH KEBUDAYAAN ISLAM DI KABUPATEN SAMBAS(Studi Kasus Pada Madrasah Ibtidaiyah SwastaDarul Ulum Matang Danau Kecamatan Paloh)." Cross Border: Jurnal Kajian Perbatasan Antarnegara, Diplomasi, Dan Hubungan Internasional 2, no. 1 (2019): 50-66.

Azizeh, Siti Nur. "METODE KISAH DALAM MENINGKATKAN MOTIVASI BELAJAR DAN KEMAMPUAN BERCERITA PADA PEMBELAJARAN SEJARAH KEBUDAYAAN ISLAM DI MADRASAH IBTIDAIYAH." Al Insyiroh: Jurnal Studi Keislaman 7, no. 1 (2021): 88-114.

Balqis, Salsabila. "Wawancara Siswa." In Siswa Kelas V MI Nurul Mun'im, 1, 2021.

Benardi, Andi Irwan. "Pendidikan Kesiapsiagaan Bencana Tanah Longsor Untuk Siswa Anak Usia Dini Dengan Metode Dongeng Berbasis Media Pop Up Book Di Paud Dewi Sartika Kecamatan Bergas." Jurnal Pendidikan Geografi 23, no. 2 (2018): 85-93. https://doi.org/10.17977/um017v23i22018p085.

Darojatun, Naila. "Wawancara Siswa." In Siswa Kelas V MI Nurul Mun'im, 1, 2021.

Emda, Amna. "Kedudukan Motivasi Belajar Siswa Dalam Pembelajaran." Lantanida Journal 5, no. 2 (2018): 172. 
https://doi.org/10.22373/lj.v5i2.2838.

Farida, Nugrahani. Metode Penelitian Kualitatif Dalam Penelitian Pendidikan Babasa. Grasindo. Vol. 1, $2014 . \quad$ http://ejournal.usd.ac.id/index.php/LLT\%0Ahttp://jurnal.untan.ac.id/in dex.php/jpdpb/article/viewFile/11345/10753\%0Ahttp://dx.doi. org/10.1016/j.sbspro.2015.04.758\%0Awww.iosrjournals.org.

Farohiyah, Safira Nayla. "Wawancara Siswa." In Siswa Kelas V MI Nurul Mun'im, 1, 2021.

Hidayah, Nurul, and Witri Anisa. "Peningkatan Motivasi Belajar Dan Kemampuan Berpikir Kritis Peserta Didik Menggunakan Model Think Pair Share Berbantuan Alat Peraga Bahan Bekas." ARRLAYAH: Jumal Pendidikan Dasar 3, no. 2 (2019): 165. https://doi.org/10.29240/jpd.v3i2.1186.

Irfangi, M. "Implementasi Metode Kisah Dalam Pembelajaran Akidah Akhlak Di Madrasah Aliyah." Jurnal Kependidikan 5, no. 1 (2017): 87-104. https://doi.org/10.24090/jk.v5i1.1255.

Irwansyah, Muhammad Ferry, and Endah Retnowati. "Efektivitas Worked Example Dengan Strategi Pengelompokan Siswa Ditinjau Dari Kemampuan Pemecahan Masalah Dan Cognitive Load." Jurnal Riset Pendidikan Matematika 6, no. 1 (2019): 62-74. https://doi.org/10.21831/jrpm.v6i1.21452.

Jumrawarsi, and Neviyarni Suhaili. "Peran Seorang Guru Dalam Menciptakan Lingkungan Belajar Yang Kondusif." Ensiklopedia Education Review 2, no. 3 (2020): 50-54.

Kamaluddin, Muhammad. "Pengaruh Motivasi Belajar Terhadap Prestasi Belajar Matematika Dan Strategi Untuk Meningkatkannya." Seminar Matematika Dan Pendidikan Matematika 67, no. 9 (2017): 455-60.

L. Ariani, and D. S. Hariyono. "Storytelling Sebagai Metode Dalam Mengembangkan Kemampuan Berbahasa Pada Anak Prasekolah." Prosiding Seminar Nasional \& Call Paper Psikologi Pendidikan, 2019, 36-44. http://fppsi.um.ac.id/wp-content/uploads/2019/07/5STORYTELLING-SEBAGAI-METODE-DALAMMENGEMBANGKAN-KEMAMPUAN-BERBAHASAPADA-ANAK-PRASEKOLAH-36-44.pdf.

Lauryn, Maya Selvia, M. Ibrohim, and Mochammad Rizqi Amirullah. "Pengembangan Metode Storytelling Berbasis Game Edukasi 
Dalam Pembelajaran Sejarah Sahabat Nabi." ProTekInfo(Pengembangan Riset Dan Observasi Teknik Informatika) 6, no. 1 (2019): 21. https://doi.org/10.30656/protekinfo.v6i1.1745.

Lestari, Dwi Puji. "Peningkatan Perilaku Anti Korupsi Melalui Metode Story Telling." Raudhatul Athfal: Jurnal Pendidikan Islam Anak Usia Dini 2, no. 1 (2018): 95-105. https://doi.org/10.19109/ra.v2i1.2238.

Lestari, Wahyu, Loviga Denny Pratama, and Jailani Jailani. "Implementasi Pendekatan Saintifik Setting Kooperatif Tipe STAD Terhadap Motivasi Belajar Dan Prestasi Belajar Matematika." AKSIOMA: Jurnal Matematika Dan Pendidikan Matematika 9, no. 1 (2018): 29. https://doi.org/10.26877/aks.v9i1.2332.

Miles, Matthew B., A. Michael Huberman, and Johnny Saldana. "Qualitative Data Analysis: A Methods Sourcebook, 3/E." In Sage Publication, Third., 341. New York: SAGE Publications, 2013.

Naim, Achmad. "APLIKASI COOPERATIF LEARNINGTIPE GROUP INVESTIGATION ( GI)PADA MATA PELAJARAN SEJARAH KEBUDAYAAN ISLAM DI KELAS V FAVORITMI SALAFIYAH SYAFI'TYAHSUKOREJO SITUBONDO, TAHUN PELAJARAN 2015/2016." Journal Al Murabbi 3, no. 1 (2016): 92-105.

Putri, Wakhidati Nurrohmah. "Pengaruh Media Pembelajaran Terhadap Motivasi Belajar Bahasa Arab Siswa Madrasah Tsanawiyah." LIS ANIA: Journal of Arabic Education and Literature 1, no. 1 (2017): 1-16. https://doi.org/10.18326/lisania.v1i1.817.

Qoimah. "Wawancara Guru.” In Wali Kelas V MI Nurul Mun'im, 1, 2021.

Raco, Jozef. "Metode Penelitian Kualitatif: Jenis, Karakteristik Dan Keunggulannya." In Grasindo. Grasindo, 2018. https://doi.org/10.31219/osf.io/mfzuj.

Ramdhani, Sandy, Nur Adiyah Yuliastri, Siti Diana Sari, and Siti Hasriah. "Penanaman Nilai-Nilai Karakter Melalui Kegiatan Storytelling Dengan Menggunakan Cerita Rakyat Sasak Pada Anak Usia Dini." Jurnal Obsesi: Jurnal Pendidikan Anak Usia Dini 3, no. 1 (2019): 153. https://doi.org/10.31004/obsesi.v3i1.108.

Ratumbuysang, Monry FNG. "Penguatan Karakter Wirausaha Melalui Metode Story Telling Sejarah Berdagang Nabi Muhammad Dan 
Sahabatnya." Jurnal Ecopsy 4, no. 3 (2017): 133. https://doi.org/10.20527/ecopsy.v4i3.4292.

Resi Amelia Syarwah, Moh. Fauziddin dan Adityawarman Hidayat. "Peningkatan Motivasi Belajar Siswa Menggunakan Media Audio Visual Pada Pembelajaran Bahasa Indonesia." Jurnal Pendidikan Tambusai 3, no. 5 (2019): 936-45.

Roizah, Zuyyimatur. "Wawancara Guru." In Guru Sejarah Kebudayaan Islam, 3:24090, 2021.

Rozi, Fathor. "Variations in Learning Methods; Upaya Dalam Mencetak Pakar Fiqh Melalui Pengembangan Pembelajaran Kitab Kuning Di Ma'had Aly." Tafaqqub: Jurnal Penelitian Dan Kajian Keislaman 9, no. 1 (2021): 81-98.

Sari, Indah Perdana, Intan Kurniasari Suwandi, and Susi Setyowati. "Pengaruh Metode Storytelling Terhadap Karakter Kerjasama Pada Siswa Kelas Iii Sd Pujokusuman Yogyakarta." Taman Cendekia: Jurnal Pendidikan Ke-SD-An 2, no. 2 (2018): 231. https://doi.org/10.30738/tc.v2i2.3078.

Saugi, W. "Peningkatan Keaktifan Dan Hasil Belajar Matematika Melalui Penerapan Model Cooperative Learning Berbasis Achievement Grouping ( Clag ).” Educasia 3, no. 1 (2018): 1-15. www.educasia.or.id.

Shopiah Atikah Dwi, Edi surya. "Penerapan Langkah Polya Dalam Menyelesaikan Soal Cerita Pada Materi Aritmatika Sosial Di SMP." Jurnal Pendidikan Matematika, no. May (2017).

Syahroni, Mashud. "PERSEPSI MAHASISWA TERHADAP MANFAAT METODE PEMBELAJARAN OBSERVASI LAPANGAN PADA MATA KULIAH PROFESI KEPENDIDIKAN." Indonesian Journal of Education and Learning 4, no. 1 (2020): 417-24. https://doi.org/10.31002/ijel.v4i1.3253.

Syaparuddin, S., M. Meldianus, and E. Elihami. "Strategi Pembelajaran Aktif Dalam Meningkatkan Motivasi Belajar PKn Peserta Didik." MAHAGURU: Jurnal Pendidikan Guru Sekolah Dasar 2, no. 1 (2020): 31-42. https://ummaspul.ejournal.id/MGR/article/download/326/154.

Ulum, Bahrul. "Metode Kisah Pendidikan Anak Usia Dini Dalam Hadits Nabi." Ta'allum: Jurnal Pendidikan Islam 8, no. 2 (2020): 202-21. https://doi.org/10.21274/taalum.2020.8.2.202-221. 
Widiyarto, Sigit, Muthia Mubasyira, Leni Tiwinyanti, Lidya Natalia Sartono, Siti Alifah, and Adhis Pamungkas. "Penguatan Pendidikan Karakter Dan Budi Pekerti Melalui Metode Story Telling Bagi Guru Pondok Darunnadwah Cikarang - Bekasi." Jurnal Pengabdian UntukMu NegeRI 4, no. 2 (2020): 222-27. https://doi.org/10.37859/jpumri.v4i2.2137.

Yusri, Yusri, Ana Rosida, Jufri Jufri, and Mantasiah R. "Efektivitas Penggunaan Media Youtube Berbasis Various Approaches Dalam Meningkatkan Motivasi Belajar Bahasa Inggris." Eralingua: Jurnal Pendidikan Bahasa Asing Dan Sastra 2, no. 2 (2018): 77-82. https://doi.org/10.26858/eralingua.v2i2.6760. 